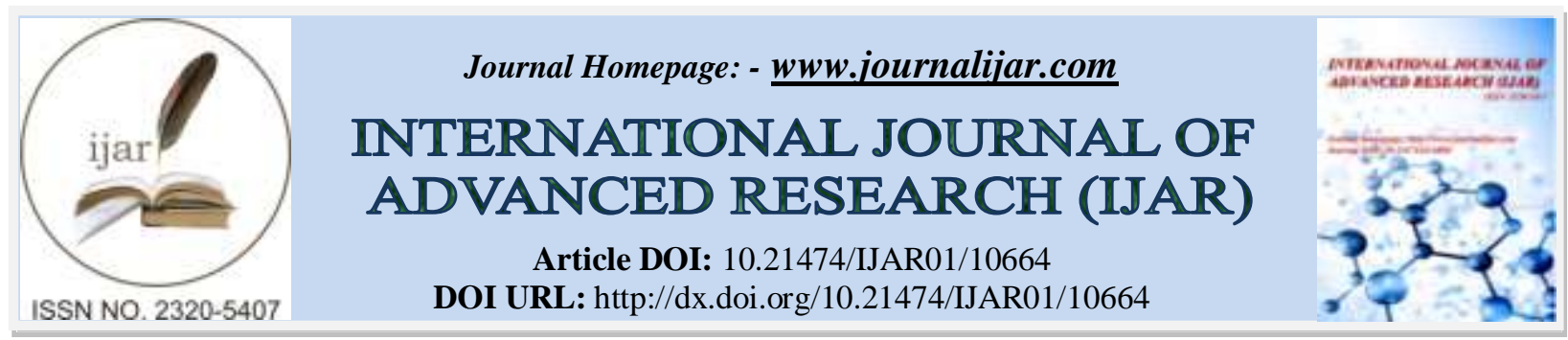

RESEARCH ARTICLE

\title{
ANALYSIS OF THE INFLUENCE OF PRICE, SERVICE QUALITY, AND BRAND IMAGE TOWARDS BUYING DECISIONS IN GOJEK APPLICATION (CASE STUDY IN JATIRANGGON, BEKASI)
}

\author{
Devina Wulandari \\ Universitas Mercubuana.
}

\begin{abstract}
Manuscript Info
Manuscript History

Received: 15 January 2020

Final Accepted: 17 February 2020

Published: March 2020

Key words:-

Price, Service Quality, Brand Image,

Buying Decision
\end{abstract}

\begin{abstract}
The development of the society forces people to travel more, either to go to work or to do other things. This makes transportation very necessary. Several parties try to offer solutions to give people alternative transportation modes, including Gojek. The aim of this research is to investigate whether price, service quality, and brand image have any influence of customers' buying decision to use Gojek. The samples for this research were taken from people in Jatiranggon, Bekasi. The method used to gather data was survey with questionnaire, and the data was analysed using SPSS 24, with path analysis method. The results showed that service quality and brand image have significant influence on customers' buying decision, while price does not.

Copy Right, IJAR, 2020,. All rights reserved.
\end{abstract}

\section{Introduction:-}

One of the characteristics of modern society is the high amount of activities, including work activities. Most people have to travel to work. In big cities like Jakarta, which has lots of traffic, this might be quite time consuming due to traffic jams. Based on data released by the Jakarta Police's Traffic Directorate (as cited from Putra, 2015), the number of motorized vehicles in Jakarta and surrounding areas has increased by 5,500 to 6,000 units vehicles per day, with 4,000 to 4,500 of them being motorcycles. As of 2014, the number of motorized vehicles in Jakarta reached 17,523,967 units, 13,084,372 of them being motorcycles.

Some parties tried to offer a solution to solve the problem of transportation in Jakarta, one of them is Gojek. Gojek started its business in 2010 by providing taxibike service through a call-center. In 2015, Gojek launched three new services: GoRide, GoSend, and GoMart. Since then, Gojek has been developed into a prominent multi-service tech platform that serves millions of users in Southeast Asia.

Gojek has proven that multi-service platform is a promising business. This is also proven by the emergence of a competitor of Gojek, Grab. Grab comes with a similar business model to Gojek, which creates competition.The following graph showed the results of the pre-survey done by 30 participants regarding the factors influencing their decision to use Gojek

Corresponding Author:- Devina Wulandari

Address:- Universitas Mercubuana. 
Fig 1.1:- Factors influencing customers' buying decision to use Gojek.

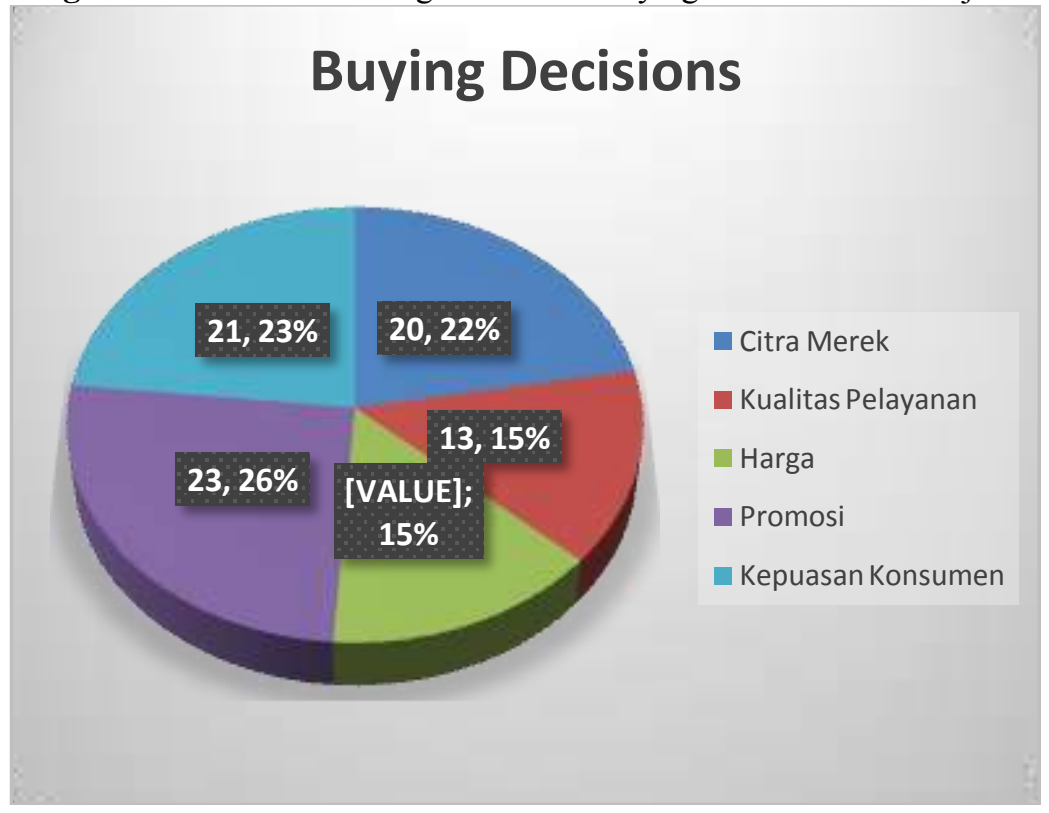

In Figure 1.1, it is shown that price is one of the most important factors influencing customers' buying decisions. Pricing is important due to various reasons. Low prices can be a trigger to improve marketing. However, some people consider price as an indicator of quality, with low price equal to low quality. Therefore, producers or service providers must be careful in deciding the prices of their products or services.

In addition to price, one of the important variables in business is the quality of service. Quality of service can be defined as an effort to deliver services to meet the needs and desires of consumers in order to meet their expectations. The relationship between the quality of service and buying decisions is proven through research conducted by Nugroho (2018) entitled "Pengaruh Kepercayaan, Kualitas Pelayanan, Harga Dan Promosi Terhadap Keputusan Pembelian Jasa Taksi Online Go-Car di Kota Solo". The results show that if the service quality given by GoCar drivers improve, more people will use GoCar. Conversely, any decline in the service quality provided by GoCar drivers will be accompanied by a decline in the number of GoCar users.

Service quality encourages users to establish strong bonds with a service provider, which can create a positive image in the minds of consumers. Brand image can be defined as a perception that arises in the minds of consumers when remembering a brand of a particular product. Furthermore, research conducted by Nugraha (2017) about the effect of price and service quality perception on brand image showed that the perception of the price of a product/service and service quality will affect the brand image of the product/service. The competition between Gojek and Grab is getting tougher, given the increasingly advanced development of the business world. The competition forces them to make various efforts so that they can survive in the competition, for example by giving discounts and promotions. In the end, the customer will choose which products and services are most satisfying and able to meet their expectations. One indicator that a company's product or service is successful or not in the market is the growth of interest towards the product or service. Because of this, Gojek must be adaptive and be able to innovate in improving its service quality and build the right brand image, to increase interest and influence the buying decisions of the customers.

The goal of this research is to investigate the influence of three variables (price, service quality, and brand image) on customers' buying decision to use Gojek. This paper is divided into five parts. In the first part, the background of this research is explained. The second part explains about the literature review of this research. In the third part, the methods used in this research are explained. In the fourth part, the results of this research are discussed. Finally, in the last part, the writer explains about the conclusion and recommendations for future research and related parties. 


\section{Literature Review:- \\ Price}

Price is the amount of money billed for a product or service, or the amount of value exchanged by customers to get the benefits of owning or using a product or service. Husein Umar defines price as the value exchanged by consumers for the benefit of owning or using a product, which is determined by the buyer and seller through bargaining or is determined by the seller for all buyers. Tandjung (2004) believes that the price is the amount of money agreed by potential buyers and sellers to be exchanged for goods or services in a normal business transaction. Quoting Pratama's research (2018) entitled "Analisis Pengaruh Citra Merek, Persepsi Harga Dan Kualitas Pelayanan Terhadap Kepuasan Pelanggan (Studi Pada Pelanggan Go-Jek Di Kota Semarang)" price perception ranks first on the magnitude of influence on customer satisfaction. Companies must try to provide a valuable offer for the goods/services offered, and the value is expressed in terms of price. According to Kotler , Armstrong, and Cunningham (2005), four indicators characterize price, namely affordability, price match with product quality. competitiveness. and price match with benefits.

\section{Service Quality}

Tjiptono (2012) defined service quality as an effort to meet the needs and desires of customers, as well as the accuracy of delivery to meet customer expectations, while Lovelock \& Wirtz (2011) defined service quality as something that consistently meets or exceeds consumer expectations. Service quality is an important factor for the company. According to Parasuraman et al. (1985), service quality is influenced by five dimensions, namely: tangible, reliability, responsiveness, assurance, and empathy.

\section{Brand Image}

Setiabudi (as cited from Margiyanto, 2013) explains that brand image is a representation of the overall perception of the brand formed from information and past experiences related to the brand. Brand image is related to the attitudes, beliefs, and preferences towards a brand. Brand image includes knowledge and trust in brand attributes (cognitive aspects), the consequences of the use of the brand, as well as evaluations, feelings and emotions perceived with the brand (affective aspects). Based on the results of studies, it can be concluded that the main dimensions that influence and shape the image of a brand according to Aaker (1991) are as follows: reputation, recognition, and loyalty.

\section{Buying Decisions}

According to Sumarwan (2010), buying decision can be defined as "How consumers decide which option to choose, including decisions about what is bought, whether to buy it or not, when to buy, where to buy, and how to pay for it". Meanwhile, Kotler and Keller (2012) stated that there are four indicators that may determine buying decisions, namely steadiness towards a product, habits in buying products, giving recommendations to others, and making repeat purchases. Based on the above rationale, the following is the relationship between variables that will be used as a theoretical framework in this study.

Fig 2.1:- Theoretical Framework.

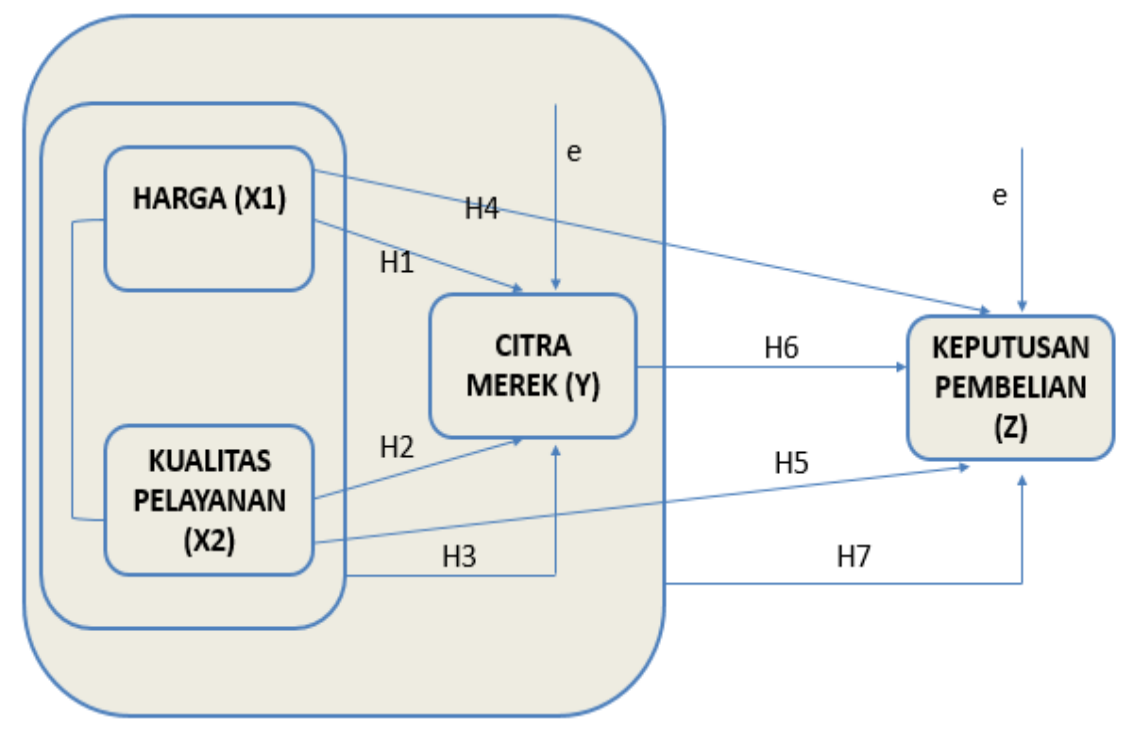




\section{Hypotheses}

Based on the theoretical framework above, several hypotheses can be made, including

H1: Price (X1) has a positive and significant effect on the brand image (Y) of Gojek.

H2: Service quality (X2) has a positive and significant effect on the brand image (Y) of Gojek.

H3: The price and service quality together (simultaneously) has a positive and significant effect on the brand image of Gojek.

H4: Price (X1) has a positive and significant effect on buying decisions (Z) on the Gojek application.

H5: Service quality (X2) has a positive and significant effect on buying decisions (Z) on the Gojek application.

H6: Brand image (Y) has a positive and significant effect on buying decisions (Y) on the Gojek application.

H7: Price and service quality have an influence on brand image and its impact on buying decisions on the Gojek application.

\section{Research Methodology:-}

Based on the research objectives that have been set, this research can be classified as quantitative research, which is a type of research that explains the influence between variables through testing hypotheses or explanatory research on populations or certain samples (Sugiyono, 2013). Quantitative analysis was chosen because determine the relationship between variables in this study, values showed in numerical form were used, focusing more on data in the form of numbers that are mathematically processed with statistical formulas. In this study, path analysis was used. Rutherford (1993) stated that path analysis is "a technique for analyzing cause and effect relationships that occur in multiple regression if the independent variable influences the dependent variable not only directly but also indirectly". The technique was used to test the level of contribution shown by the path coefficient on each path diagram of the causal relationship between independent variables, namely price (X1) and service quality (X2) on the intervening variable (brand image $(\mathrm{Y})$ ) and the impact on the dependent variable (buying decisions $(\mathrm{Z})$ ).

In this study, the number of samples was determined using the Slovin formula. 100 respondents in Jatiranggon were chosen. The sampling technique used in this study was probability sampling with a random sampling method, which is a technique for obtaining samples that are directly carried out on the sampling unit. In simple random sampling, the sampling of members of the population is done randomly without regard to strata that exist in that population. It means that each sampling unit as an isolated element of the population has the same opportunity to be sampled or to represent the population.

\section{Results and Discussion:- \\ Respondents}

The number of samples used in this study was 100 , with $48 \%$ of respondents were male and the rest $52 \%$ were women. $62 \%$ of the respondents aged between $15-25$ years old, $22 \%$ aged between $26-35$ years old, $12 \%$ aged between 36-45 years old and 4\% aged between $46-55$ years The most recent education received by $3 \%$ of the respondents was elementary school education, $56 \%$ has received high school / vocational school education, $12 \%$ has received associate degree, and $21 \%$ has received bachelor degree.

\section{Reliability Test}

An instrument can be considered reliable if the instrument can produce consistent data if measurements are done twice or more. An instrument can be considered reliable if the Cronbach's Alpha coefficient of all the variables is higher than 0.60 (Ghozali, 2011). The reliability test results for each variable in this research are shown in Table 4.2.

Table 4.2.1.:- Results of Reliability Test.

Variable Cronbach's Alpha

\begin{tabular}{|c|c|}
\hline Variable & Cronbach's Alpha \\
\hline Price & 0,675 \\
\hline Service Quality & 0,726 \\
\hline Brand Image & 0,709 \\
\hline Buying Decisions & 0,708 \\
\hline
\end{tabular}

Table 4.2.1 shows that all variables have a Cronbach's Alpha coefficient that is higher than 0.60, which means that the questionnaire can be considered reliable or consistent.

4.3. Normality Test 
Normality test is done in order to check whether the sample data has been obtained from a normally distributed population (Strickland, 2012), which is a requirement for the following test. In this research, the normality test was done using Kolmogorov-Smirnov test. If the significance value is more than 0.05 , then the data can be considered as normally distributed.The results of Kolmogorov-Smirnov test are shown as follows:

Table 4.3.1.:- One Sample Kolmogorov-Smirnov Test (Dependent Variable "Brand Image" (Y)).

\begin{tabular}{|l|l|r|}
\hline N & Mean & 100 \\
\hline Normal Parameters & a,b &, 0000000 \\
\cline { 2 - 3 } & Std. Deviation &, 91140665 \\
\hline \multirow{2}{*}{ Most Extreme Differences } & Absolute &, 068 \\
\cline { 2 - 3 } & Positive &, 068 \\
\cline { 2 - 3 } & Negative &,- 065 \\
\hline \multicolumn{2}{|l|}{} &, 068 \\
\hline Test Statistic &, $200^{\text {c,d }}$ \\
\hline
\end{tabular}

Table 4.3.2.:- One Sample Kolmogorov-Smirnov Test (Dependent Variable "Keputusan Pembelian" (Z)).

\begin{tabular}{|l|l|r|}
\hline N & Mean & 100 \\
\hline Normal Parameters &, 0000000 \\
\cline { 2 - 3 } & Std. Deviation &, 53112896 \\
\hline \multirow{3}{*}{ Most Extreme Differences } & Absolute &, 073 \\
\cline { 2 - 3 } & Positive &, 073 \\
\cline { 2 - 3 } & Negative &,- 042 \\
\hline \multicolumn{2}{|l|}{ Test Statistic } &, 073 \\
\hline Asymp. Sig. (2-tailed) &, $200^{\mathrm{c}, \mathrm{d}}$ \\
\hline
\end{tabular}

To ensure further that the data is normally distributed, P-Plot test was done. According to Ghozali (2011), if the data (spots in the graph) is close to the diagonal line in the graph, then the data can be considered as normally distributed. The results of P-Plot test are shown as follows:

Figure 4.3.1:- Results of P-Plot test (Model 1).

Normal P-P Plot of Regression Standardized Residual

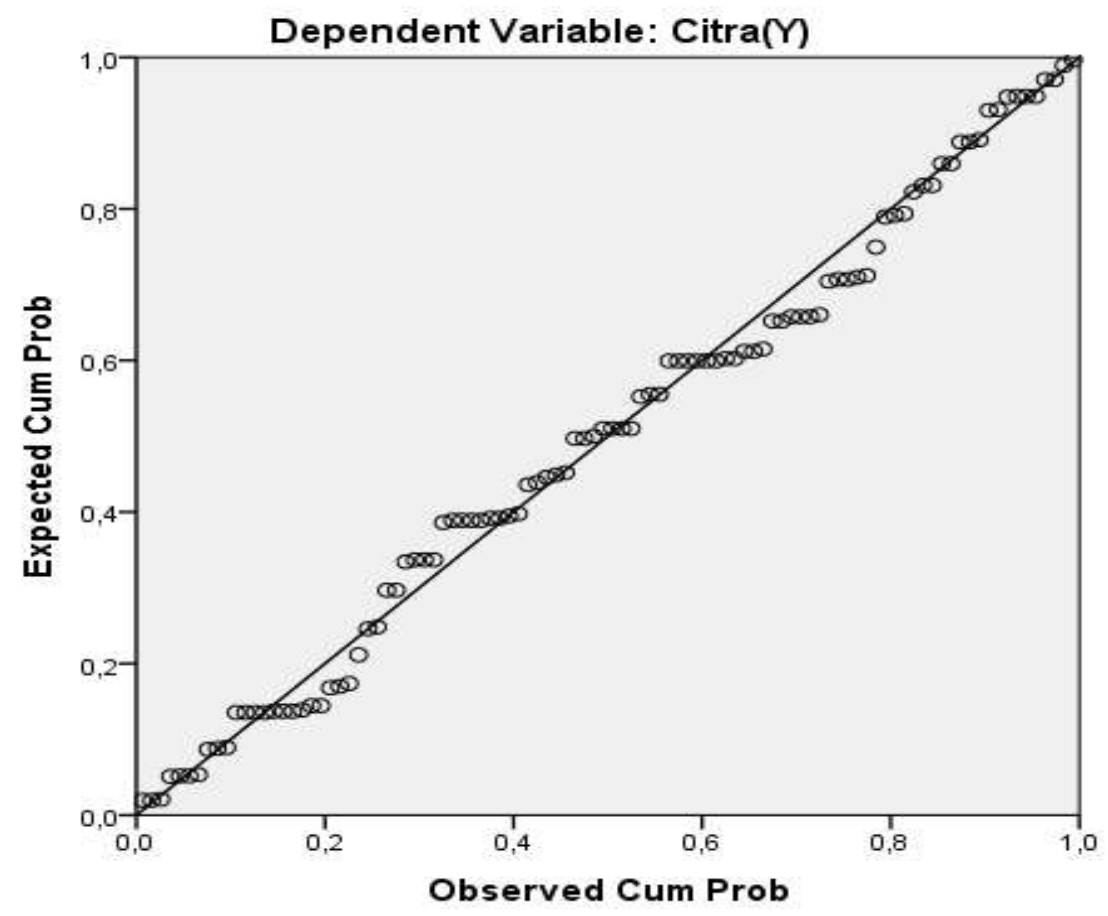


Figure 4.3.2:- Results of P-Plot test (Model 2).

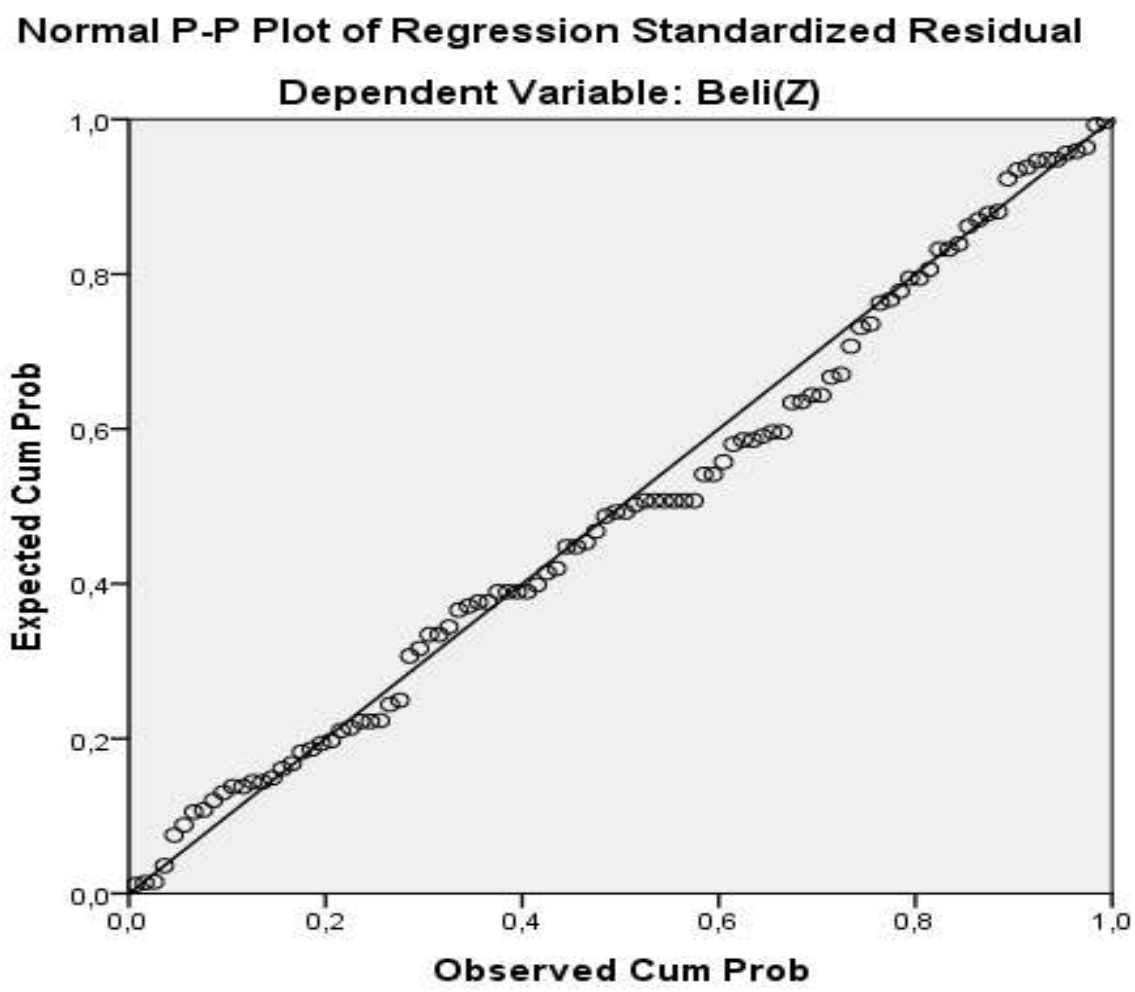

The results of the Kolmogorov-Smirnov tests show that the significance values are higher than 0.05. Furthermore, according to the results of P-Plot tests, the data are close to the diagonal line. These results show that the data is normally distributed.

\section{Linearity Test}

Linearity test is done to determine whether two variables have a significant linear relationship. Tests carried out using SPSS. If the Deviation for Linearity value for the relationship between the two variables is above 0.05, then the linearity of the two variables is significant (Ghozali, 2011). The results are presented in the following table.

\begin{tabular}{|l|l|l|}
\hline Variables & Deviation For Linearity & Notes \\
\hline Price-Brand Image & 0.890 & Significant \\
\hline Service Quality- Brand Iamge & 0.460 & Significant \\
\hline Price-Buying Decision & 0.757 & Significant \\
\hline Service Quality-Buying Decision & 0.336 & Significant \\
\hline Brand Image- Service Quality & 0.048 & Insignificant \\
\hline
\end{tabular}

Because based on these test results, the relationship between brand image variables and purchase quality is considered insignificant, the authors use a second test P-Plot for both of these variables, with the following results. 


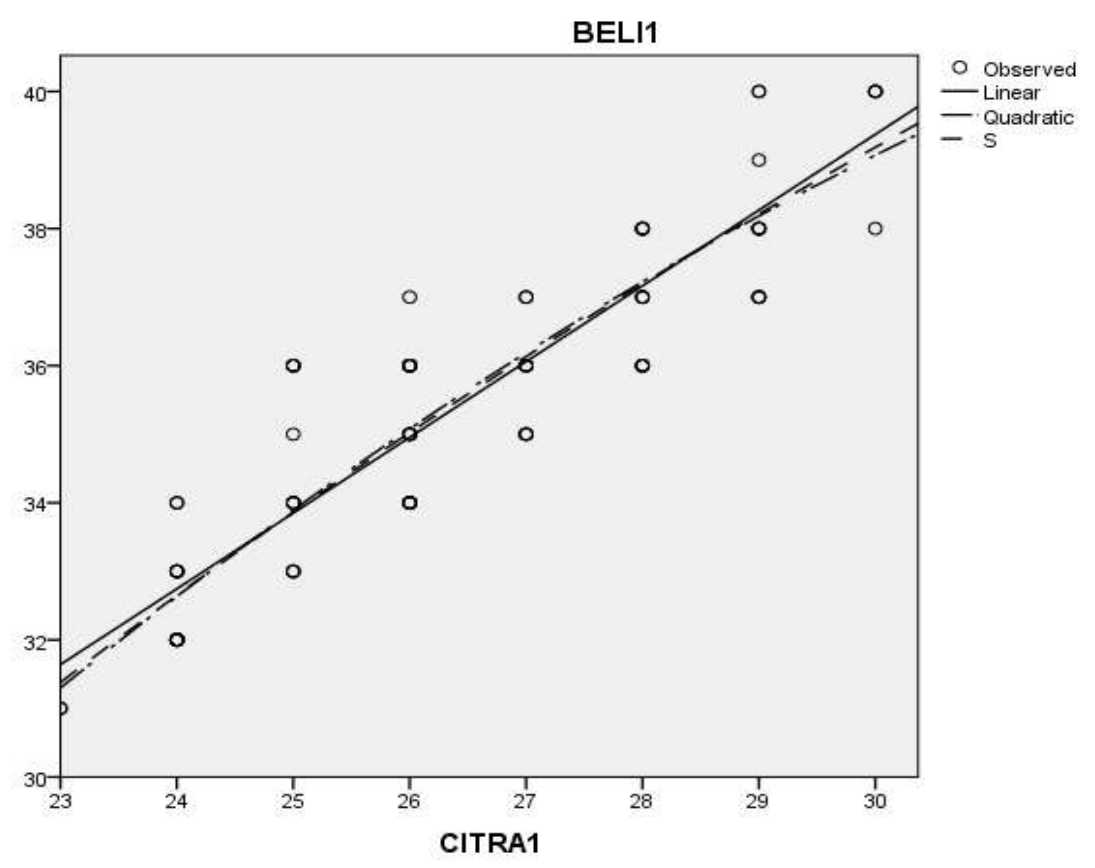

As the graph above shows, it can be seen that the relationship model that is most closely related to the variable tested is the linear model. Thus, it can be concluded that brand image and buying decisions variables have linear relationship.

\section{Hypotheses Test}

As mentioned earlier, in this study, the author used two regression models. The first model focuses on the effect of the dependent variable (price and service quality) on the intervening variable (brand image), while the second model focuses on the effect of the dependent and intervening variable on the independent variable (buying decisions).

To test the effect of one variable on another variable, the author conducted the t-test, while to measure the effect of two or more variables on another variable, the authors conducted the f-test. Indication that one or more variables have significant and positive influence on other variables is that when the significance value is lower than 0.05 (Ghozali, 2011). The results of the tests on regression model 1 are shown as follows:

\section{Results of f-test on regression model 1}

Model Summary

\begin{tabular}{|l|l|l|l|l|}
\hline \multicolumn{4}{|l|}{ Model Summary } \\
\hline Model & $\mathrm{R}$ & R Square & Adjusted R Square & Std. Error of the Estimate \\
\hline 1 &, $877^{\mathrm{a}}$ &, 769 &, 765 &, 921 \\
\hline
\end{tabular}

\begin{tabular}{|l|l|l|l|l|l|}
\hline & $\begin{array}{l}\text { Sum } \\
\text { Squares }\end{array}$ & Df & Mean Square & F & Sig. \\
\hline Regression & 274,204 & 2 & 137,102 & 161,717 &, $000^{\mathrm{b}}$ \\
\hline Residual & 82,236 & 97 &, 848 & & \\
\hline Total & 356,440 & 99 & & & \\
\hline
\end{tabular}

a. Dependent Variable: CITRA_TOTAL

b. Predictors: (Constant), KP_TOTAL, HARGA_TOTAL

Results of t-test on regression model 1 Coefficients

\begin{tabular}{|c|c|c|c|c|}
\hline \multirow[t]{2}{*}{ Model } & & efficients & \multirow{2}{*}{$\begin{array}{l}\text { Standardized } \\
\text { Coefficients }\end{array}$} & \multirow[t]{2}{*}{$\mathrm{t}$} \\
\hline & B & Std. Error & & \\
\hline
\end{tabular}




\begin{tabular}{|l|l|l|l|l|l|}
\hline (Constant) & $-1,067$ & 1,558 & &,- 685 &, 495 \\
\hline HARGA_TOTAL &,- 007 &, 092 &,- 008 &,- 075 &, 940 \\
\hline KP_TOTAL &, 626 &, 075 &, 884 & 8,369 &, 000 \\
\hline
\end{tabular}

Dependent Variable: CITRA_TOTAL

The formula for the regression model is shown as follows:

$\mathrm{Y}($ Brand image $)=0.940 \mathrm{X} 1$ (Price) $+0.000 \mathrm{X} 2$ (Service Quality $)+0.231(1-\mathrm{r}$ square $(0.769))$

The results of the hypothesis tests are explained as follows:

H1

The results of the t-test shown that the significance value of "Price" variable is 0.940 . Because the value is higher than 0.05 , it can be concluded that the variable does not affect the intervening variable "brand image". Thus, H1 can be rejected. Price is one of the main factors for buyers in deciding whether they will buy a product or service. Entrepreneurs need to pay attention to prices, because in business competition, prices offered by competitors can be lower with the same quality or even with better quality.

H2

The results of the t-test shown that the significance value of "Service Quality" variable is 0.00 . Because the value is smaller than 0.05 , it can be concluded that the variable has a significant effect on the intervening variable "brand image". Thus, $\mathrm{H} 2$ can be accepted. It is undeniable that the quality of services provided will form certain memories that are embedded in the minds of consumers as well as being one of the factors that will determine whether consumers will re-use products or not. The results of this study are in line with research conducted by Rizan, Yulianti, and Rahmi (2015) which states that service quality has a positive and significant effect on brand image of Gojek.

\section{H3}

The results of the t-test shown that the significance value is 0.000 . 0.00 . Because the value is smaller than 0.05 , it can be concluded that the variables simultaneously have a significant effect on the intervening variable "brand image". Thus, $\mathrm{H} 3$ can be accepted.

\section{Results of t-test on regression model 2}

Coefficients

\begin{tabular}{|l|l|l|l|l|l|}
\hline \multirow{2}{*}{ Model } & \multicolumn{2}{|l|}{ Unstandardized Coefficients } & $\begin{array}{l}\text { Standardized } \\
\text { Coefficients } \\
\text { Beta }\end{array}$ & Std. Error & Sig. \\
\cline { 2 - 6 } & $\mathrm{B}$ &, 915 & &,- 713 &, 477 \\
\hline (Constant) &,- 653 &, 054 &,- 044 &,- 853 &, 396 \\
\hline HARGA_TOTAL &,- 046 &, 058 &, 749 & 11,181 &, 000 \\
\hline KP_TOTAL &, 643 &, 059 &, 288 & 5,874 &, 000 \\
\hline CITRA_TOTAL &, 349 & -000 & \multicolumn{2}{l|}{} \\
\hline
\end{tabular}

a.

Dependent Variable: CITRA_TOTAL

The formula for the regression model is shown as follows:

$\mathrm{Z}($ Buying Decision $)=0.396 \mathrm{X} 1($ Price $)+0.000 \mathrm{X} 2$ (Service Quality $)+0.000 \mathrm{Y}($ Brand Image $)+0.053$ (1- r square (0.947))

The results of the hypothesis tests are explained as follows:

H4

The results of the t-test shown that the significance value of "Price" variable is 0,396 . Because the value is higher than 0.05 , it can be concluded that the variable does not affect the dependant variable "buying decision". Thus, H4 can be rejected. The results of this study are in line with research conducted by Arslan and Zaman (2014) regarding buying interest in retail stores, which showed that price did not have a significant influence on buying interest. This is because according to consumers, the price of the product being sold matches with the value of the product.

\section{H5}

The results of the t-test shown that the significance value of "Service Quality" variable is 0.00 . Because the value is smaller than 0.05 , it can be concluded that the variable has a significant effect on the dependant variable "buying 
decision". Thus, H5 can be accepted.Dengan demikian, hipotesis H5 dapat dinyatakan diterima. The results are in line with research conducted by Hamid, Siambaton and Yanuar (2016) that there is a positive and significant influence on the quality of service on the customers' decision to use Go-Jek online taxi services.

\section{H6}

The results of the t-test shown that the significance value of "Service Quality" variable is 0.00 . Because the value is smaller than 0.05 , it can be concluded that the variable has a significant effect on the dependant variable "buying decision". Thus, H6 can be accepted. The results are in line with the results of the research conducted by Musay (2013), which showed that brand image have a significant relationship on buying decisions.

\section{H7}

To test the hypothesis, the author compared the value of the direct influence of "Price" and "Service Quality" variables on buying decisions, and the influence of these two variables through the intervening variable ("Brand Image").

a. Price

The direct influence of "Price" on "Buying Decisions" is -0.044 , while its influence through the intervening variable is $-0.008 \times 0.288=-0.002304$. Since the indirect influence is smaller than the direct influence, it can be concluded that "Price" does not have a significant indirect influence of "Buying Decision".

b. Effect of Service Quality Variables Through Brand Image

The direct influence of "Service Quality" on "Buying Decisions" is 0.749 , while its influence through the intervening variable is $0.884 \times 0.288=0.254592$. Since the indirect influence is smaller than the direct influence, it can be concluded that "Service Quality" does not have a significant indirect influence of "Buying Decision". Thus, it can be concluded that $\mathrm{H} 7$ cannot be accepted.

\section{Conclusion and Recommendation:- Conclussion:-}

Based on data collected and analyzed, it is known that the hypotheses $\mathrm{H} 2, \mathrm{H} 3, \mathrm{H} 5$, and $\mathrm{H} 6$ can be accepted, while the hypotheses H1, H4, and H7 cannot be accepted.

\section{Recommendations:-}

The results of the research showed that the variables "Service Quality" and "Brand Image" have a significant influence to customers' buying decision. Therefore, the writer recommends Gojek to pay more attention to these two variables in order to attract more customers to use Gojek and its services.

Aside from the variables used in this research, there are other variables that may also have some influence to customers' buying decisions, such as promotion, loyalty program and consumer satisfaction. Therefore, the writer recommends other researchers to conduct research to investigate the influence of those variables.

\section{References:-}

1. Aaker, D.A. (1991). Managing Brand Equity. New York: John Wiley \& Sons Inc.

2. Arslan, M. \& Zaman. R. (2014). Impact of Brand Image and Service Quality on Consumer Purchase Intention: A Study of Retail Store in Pakistan. Research on Humanities and Social Sciences, 4 (22).

3. Ghozali, I. (2011). Aplikasi Analisis Multivariate Dengan Program SPSS. Semarang: Badan Penerbit Universitas Diponegoro.

4. Hamid, F.Z., Siambaton, E., \& Yanuar, M.K. (2016). Pengaruh Kualitas Pelayanan Jasa Terhadap Keputusan Pembelian Pada Pengguna Jasa Ojek Online Go-Jek (Studi Kasus Di Politeknik Negeri Jakarta Jurusan Administrasi Bisnis). Epigram, 13(1).

5. Kotler, P., Armstrong, G., \& Cunningham, M. H. (2005). Principles of marketing. Toronto: Pearson Prentice Hall.

6. Kotler, P., Keller., Lane, K. (2012 ). Marketing Management (14th Global Ed). New Jersey: Printice Hall.

7. Lovelock, C.H. \& Wirtz, J. (2011). Services Marketing: People, Technology, Strategy (7th ed.). Boston: Pearson.

8. Margiyanto. M, (2013). Analisis Pengaruh Citra Merek, Persepsi Harga, Kualitas Produk, dan Promosi Terhadap Keputusan Pembelian Blackberry di Kota Semarang. (Bachelor's thesis, Universitas Diponegoro, Semarang, Indonesia). Retrieved from http://eprints.undip.ac.id/40156/1/MARGIYANTO.pdf 
9. Musay, F.P. (2013). Pengaruh Brand Image Terhadap Keputusan Pembelian (Survei Pada Konsumen KFC Kawi Malang). Jurnal Administrasi Bisnis. 3(2).

10. Nugraha, S.S. (2017). Pengaruh Persepsi Harga Dan Kualitas Pelayanan Terhadap Citra Merek Dalam Meningkatkan Minat Menggunakan Go-Jek (Studi Pada Go-Jek Di Kota Semarang). (Masters thesis, Universitas Diponegoro, Semarang, Indonesia). Retrieved from http://eprints.undip.ac.id/58424/

11. Nugroho. R. (2018). Pengaruh Kepercayaan, Kualitas Pelayanan, Harga Dan Promosi Terhadap Keputusan Pembelian Jasa Taksi Online Go-Car di Kota Solo. (Bachelor's thesis, Universitas Muhammadiyah Surakarta, Surakarta, Indonesia). Retrieved from http://eprints.ums.ac.id/66788/

12. Parasuraman, A., Zeithaml, V.A. \& Berry, L.L. (1985), A conceptual model of service quality and its implications for future research, Journal of Marketing, 49(3), pp. 41-50.

13. Pratama, R.A. (2018). Analisis Pengaruh Citra Merek, Persepsi Harga Dan Kualitas Pelayanan Terhadap Kepuasan Pelanggan (Studi Pada Pelanggan Go-Jek Di Kota Semarang). (Bachelor's thesis, Universitas Diponegoro). Retrieved from http://eprints.undip.ac.id/65896/1/06_PRATAMA.pdf

14. Putra, E.P (2015, January 9). Polda Metro: Kendaraan Bermotor di Jakarta Bertambah 6.000 per Hari. Republika. Retrieved from https://www.republika.co.id।

15. Rizan, M., Yulianti,D., \& Rahmi. (2015). The Influence of Price and Service Quality of Brand Image and Its Impact on Customer Satisfaction Gojek (Students Study On A State University Of Jakarta). Jurnal Riset Manajemen Sains Indonesia (JRMSI), 6(2), pp. 639-568.

16. Rutherford, R.,(1993). Statistical Model For Causal Analysis. New York: John Wiley and Sons Inc.

17. Strickland, J. (2012). Discrete Event Simulation Using ExtendSim 8. Colorado Springs, CO: Lulu.Inc.

18. Sugiyono.(2013). Metode Penelitian Kuantitatif, Kualitatif, dan R \& D. Bandung : Alfabeta

19. Suwarman, U. (2010). Perilaku Konsumen. Bogor: Ghalia Indonesia.

20. Tandjung, J.W. (2004). Marketing Management : Pendekatan Pada Nilai-Nilai Pelanggan (2nd ed.). Malang: Bayumedia Publishing.

21. Tjiptono, F. (2012). Strategi Pemasaran (3rd ed.). Yogyakarta: Andi. 